Annals of Plant and Soil Research 23(2): 135-139 (2021)

https://doi.org/10.47815/apsr.2021.10045

\title{
Effect of sulphur and zinc management on yield, quality and nutrient uptake in pearl millet (Pennisetum glaucum) - lentil (Lens culinaris) crop sequence
}

\author{
KAUSHAL YADAV AND VINAY SINGH
}

\author{
Department of Agricultural Chemistry and Soil Science, Raja Balwant Singh College Bichpuri, Agra (U.P.) \\ 283105
}

Received: January, 2021, Revised accepted: March, 2021

\begin{abstract}
A field experiment was conducted at Panwari village of Agra district during Kharif and rabi season of 2015-16 and 2016-17 to study the effect of sulphur and zinc management on yield, nutrient uptake and residual soil fertility under pearl millet (Pennisetum glaucum) - lentil (Lens culinaris Medikus) crop sequence. Four levels each of sulphur and zinc were evaluated under randomized block design with three replications. Both the nutrients were applied to pearl millet and their direct and residual response was ascertained to pearl millet and lentil in sequence. Pooled results indicated that grain and stover yield of pearl millet improved significantly with increasing levels of $S$ up to $20 \mathrm{~kg} \mathrm{~S}$ ha ${ }^{-1}$ over control. An increase of 17.0 and $16.5 \%$ in grain and stover yield was recorded with $20 \mathrm{~kg} \mathrm{~S} \mathrm{ha-1} \mathrm{over} \mathrm{control.} \mathrm{Similarly,} \mathrm{grain} \mathrm{and} \mathrm{stover} \mathrm{yield} \mathrm{of} \mathrm{pearl} \mathrm{millet} \mathrm{increased}$ significantly with $\mathrm{Zn}$ and maximum grain $\left(3.46 \mathrm{th} \mathrm{h}^{-1}\right)$ and stover $\left(8.19 \mathrm{tha}^{-1}\right)$ yields were recorded with $4 \mathrm{~kg} \mathrm{Zn}$ $\mathrm{ha}^{-1}$. The content and yield of protein in both the crops increased significantly with the addition of $S$ and $Z n$ over control. The residual effect of $S$ in lentil was significant at $40 \mathrm{~kg} \mathrm{~S} \mathrm{ha}^{-1}$ and grain and straw yield increments were to the extent of 18.6 and 15.8 per cent, respectively. The residual effect of $6 \mathrm{~kg} \mathrm{Zn} \mathrm{ha-1}$ on succeeding lentil crop produced 16.7 and $14.0 \%$ higher grain and straw yield over control, respectively. Application of $S$ and $\mathrm{Zn}$ showed significantly beneficial effect on $S$ and $Z n$ uptake by pearl millet and succeeding lentil crop over control. Nitrogen and P uptake by both the crops also improved significantly with these elements over contro
\end{abstract}

Keywords: Sulphur, zinc, nutrient uptake, pearl millet- lentil crop sequence, yield.

\section{INTRODUCTION}

Pearl mielt (Pennisetum glaucum) and lentil (Lens culinaris Medikus) are very important crops in the Agra region of Uttar Pradesh for their contribution to human and animal nutrition as components of cropping system and as restorers of soil fertility. Pearl millet - lentil cropping system is prefaced with no application of chemical fertilizer only to pearl millet. This crop sequence is also important as it requires low water inputs and labour in comparison to other pearl millet based systems. Our soils have been exhausted in respect of major and minor elements hampering the yield of crops. There is stagnation and deterioration in productively of both crops in a crop sequence as well as on individual basis because sulphur and zinc deficiency is very common in light textured soils of Agra where high intensive cropping of pearl millet wheat is practiced (Singh and Singh 2020). Sulphur plays an important role in improving yield and quality of the crops. It plays an important role in the formation of $S$ containing amino acids which act as building blocks in the synthesis of protein. It has a role in play in increasing chlorophyll formation and aiding photosynthesis. Sulphur plays a role in the activation of enzymes nucleic acids and forms parts of blotin and thiamine. Zinc is essential for promoting certain metabolic reactions. It is necessary for the production of chlorophyll and carbohydrates. Zinc is directly or indirectly required by several enzymes auxin and protein synthesis. The nutrients applied in one crop are not fully utilized which leads to their residual effect on succeeding crop. Thus, there is a need to study the role of $S$ and $Z n$ in sustainable production of pearl millet and lentil crops. The information on direct and residual effects of sulphur and zinc in pearl millet-lentil crop sequence in Agra region is meager. Hence the present investigation was carried out to study the response of $S$ and $Z n$ on pearl millet-lentil crop sequence in Agra region. 


\section{MATERIALS AND METHODS}

A field experiment was conducted at farmer field of Panwari village of Agra district (U.P.) during 2015-16 and 2016-17 in randomized block design replicated thrice. The texture of soil of experiment field was sandy loam with $\mathrm{pH}$ value of 7.8 , organic carbon $3.2 \mathrm{~g}$ $\mathrm{kg}^{-1}$, available $\mathrm{N} 180 \mathrm{~kg} \mathrm{ha}^{-1}$, available $\mathrm{P} 9.0 \mathrm{~kg}$ $\mathrm{ha}^{-1}$, available $\mathrm{K} 115 \mathrm{~kg} \mathrm{ha}^{-1}$, Sulphur $16.2 \mathrm{~kg} \mathrm{ha}$ ${ }^{1}$ and zinc $0.52 \mathrm{mg} \mathrm{kg}^{-1}$. Four levels each of $S(0$, 10,20 and $\left.40 \mathrm{~kg} \mathrm{ha}^{-1}\right)$ and $\mathrm{Zn}(0,2,4$, and $6 \mathrm{~kg}$ $\left.\mathrm{ha}^{-1}\right)$ were applied as elemental sulphur and zinc chloride, respectively as per treatments. Both $S$ and $\mathrm{Zn}$ applied to pearl millet crop and their direct effects on pearl millet and residual effect on lentil was studied. Recommended dose of the $\mathrm{N}, \mathrm{P}$ and $\mathrm{K}$ were applied to both the crops as urea, diammonium phosphate and muriate of potash, respectively. Pearl millet was sown in first week of July in both the years using seed rate of $5 \mathrm{~kg} \mathrm{ha}^{-1}$. After harvest of pearl millet, lentil was sown during third week of November in both years. Crops were harvested at physiological maturity. The yields of both the crops were recorded at harvest. Grain and straw samples were digested in diacid mixture of $\mathrm{HNO}_{3}, \mathrm{HClO}_{4} \quad(10: 4)$ and $\mathrm{S}$ content was determined turbidimetrically (Chesnin and Yien 1951). Phosphorus and $\mathrm{Zn}$ in acid digest were determined by vanadate molybldate yellow colour method and atomic absorption spectrophotometer, respectively. Nitrogen content was determined by modified Kjeldahl method (Jackson 1973) and protein content was calculated by multiplying with a factor of 6.25 . The uptake of nutrients was obtained as product of their concentration and yield. The data then obtained were analysed statistically using analysis of variance technique for various parameters at $5 \%$ level of significance.

\section{RESULTS AND DISCUSSION}

\section{Direct effect on pearl millet}

The data (Table 1) revealed that the grain and stover yield of pearl millet increased significantly with sulphur application up to $20 \mathrm{~kg}$ $\mathrm{S} \mathrm{ha}^{-1}$ over control. The magnitude of response to $20 \mathrm{~kg} \mathrm{~S} \mathrm{ha}^{-1}$ on grain and stover yield of pearl millet was 17.0 and $16.5 \%$ over control, respectively. This may be attributed to low availability of $S$ in soil. In addition, the higher yield with sulphur may be due to favorable effect on growth and ultimately on yield. Singh and Singh (2020) and Yadav and Singh (2021) also reported higher yield of pearl millet with sulphur addition. Significantly highest grain yield (3.46t $\mathrm{ha}^{-1}$ ) of pearl millet was recorded under application of $4 \mathrm{~kg} \mathrm{Zn} \mathrm{ha-1}$ followed by a reduction at $6 \mathrm{~kg} \mathrm{Zn} \mathrm{ha}^{-1}$. With the application of $4 \mathrm{~kg} \mathrm{Zn}$ ha $^{-1}$, increase of $14.8 \%$ was recorded in pearl millet grain yield over control. The corresponding increase in stover yield was 10.7 per cent. The response of $\mathrm{Zn}$ application may be attributed to low status $\left(0.52 \mathrm{mg} \mathrm{kg}^{-1}\right)$ of available $\mathrm{Zn}$ in Soil. Singh and Pandey (2018) also reported significant response of applied $\mathrm{Zn}$ to pearl millet in alluvial soil.

Table 1: Effect of sulphur and zinc on yield and quality of pearl millet and lentil ( mean of 2 Years)

\begin{tabular}{|c|c|c|c|c|c|c|c|c|}
\hline \multirow{2}{*}{ Treatment } & \multicolumn{2}{|c|}{ Pearl millet Yield $\left(\mathrm{t} \mathrm{ha}^{-1}\right)$} & \multirow{2}{*}{$\begin{array}{c}\text { Protein } \\
(\%)\end{array}$} & \multirow{2}{*}{$\begin{array}{c}\text { Protein } \\
\text { Yield }\left(\mathrm{kg} \mathrm{ha}^{-1}\right)\end{array}$} & \multicolumn{2}{|c|}{ Lentil yield $\left(\mathrm{t} \mathrm{ha}^{-1}\right)$} & \multirow{2}{*}{$\begin{array}{c}\text { Protein } \\
(\%)\end{array}$} & \multirow{2}{*}{\begin{tabular}{|c|} 
Protein \\
Yield $\left(\mathrm{kg} \mathrm{ha}^{-1}\right)$ \\
\end{tabular}} \\
\hline & Grain & Strow & & & Grain & Straw & & \\
\hline \multicolumn{9}{|c|}{ Sulphur (kg ha $\left.{ }^{-1}\right)$} \\
\hline 0 & 2.95 & 7.51 & 10.1 & 298.0 & 1.61 & 2.09 & 22.8 & 367.0 \\
\hline 10 & 3.20 & 8.26 & 10.3 & 329.6 & 1.73 & 2.23 & 22.9 & 396.1 \\
\hline 20 & 3.45 & 8.76 & 10.5 & 362.2 & 1.89 & 2.42 & 23.1 & 436.5 \\
\hline 40 & 3.40 & 8.57 & 10.6 & 360.4 & 1.91 & 2.44 & 23.2 & 466.0 \\
\hline $\mathrm{CD}(\mathrm{P}=0.05)$ & 0.18 & 0.42 & 0.03 & 14.8 & 0.11 & 0.15 & 0.04 & 17.4 \\
\hline \multicolumn{9}{|l|}{ Zinc $\left(\mathrm{Kg} \mathrm{ha}^{-1}\right)$} \\
\hline 0 & 3.10 & 7.93 & 10.2 & 316.2 & 1.64 & 2.13 & 22.9 & 375.5 \\
\hline 2 & 3.19 & 8.13 & 10.4 & 331.7 & 1.72 & 2.21 & 23.0 & 395.6 \\
\hline 4 & 3.46 & 8.78 & 10.5 & 363.3 & 1.83 & 2.41 & 23.1 & 422.7 \\
\hline 6 & 3.35 & 8.19 & 10.6 & 355.1 & 1.90 & 2.43 & 23.1 & 437.9 \\
\hline $\mathrm{CD}(\mathrm{P}=0.05)$ & 0.18 & 0.42 & 0.03 & 14.8 & 0.11 & 0.15 & 0.04 & 17.4 \\
\hline
\end{tabular}


Increasing levels of $S$ and $\mathrm{Zn}$ significantly improved the protein content in pearl millet grain over control. The protein content in grain increased from 10.1 to $10.6 \%$ with $40 \mathrm{~kg} \mathrm{~S}$ $\mathrm{ha}^{-1}$. The corresponding increase in protein content in pearl millet grain with $6 \mathrm{~kg} \mathrm{Zn} \mathrm{ha}^{-1}$ was from 10.2 to 10.6 per cent. The increase in protein content owing to $S$ addition may be attributed to its involvement in amino acid synthesis. Similar resents were also reported by Chauhan et al. (2017). The protein yield also increased significantly from 298.0 to $362.2 \mathrm{~kg}$ ha ${ }^{1}$ with $20 \mathrm{~kg} \mathrm{~S} \mathrm{ha}^{-1}$ and from 316.2 to $363.3 \mathrm{~kg}$ $\mathrm{ha}^{-1}$ with $4 \mathrm{~kg} \mathrm{Zn} \mathrm{ha}^{-1}$, respectively. The protein yield is more influenced by grain yield and thus followed almost trend similar to grain yield (Chauhan et al. 2017).

Nitrogen uptake in grain and stover of pearl millet increased significantly with the progressive increase in $S$ application from 0 to $40 \mathrm{~kg} \mathrm{ha}^{-1} \mathrm{~S}$ application. The maximum uptake of nitrogen in grain $\left(58.4 \mathrm{~kg} \mathrm{ha}^{-1}\right)$ and stover $(60.8$ $\mathrm{kg} \mathrm{ha}^{-1}$ ) was associated with $40 \mathrm{~kg} \mathrm{~S} \mathrm{ha}^{-1}$. There was a significant increase in $\mathrm{N}$ uptake in pearl millet grain and stover with increasing levels of $\mathrm{Zn}$ and the maximum values were recorded with $4 \mathrm{~kg} \mathrm{Zn} \mathrm{ha-1}$. Phosphorus uptake of $6.4,7.2$ and $7.4 \mathrm{~kg} \mathrm{ha}^{-1}$ in grain and $8.2,10.0$ and $10.2 \mathrm{~kg}$ $\mathrm{ha}^{-1}$ in stover were recorded under 10, 20 and $40 \mathrm{~kg} \mathrm{~S} \mathrm{ha}^{-1}$ respectively, which were significantly higher over control values (5.3 and $\left.6.7 \mathrm{~kg} \mathrm{ha}^{-1}\right)$. Zinc application increased the phosphorus uptake by pearl millet grain and stover up to $4 \mathrm{~kg} \mathrm{Zn} \mathrm{ha-1} \mathrm{followed} \mathrm{by} \mathrm{a} \mathrm{reduction}$ at $6 \mathrm{~kg} \mathrm{Zn} \mathrm{ha}^{-1}$. The decreased in $\mathrm{P}$ uptake with $6 \mathrm{~kg} \mathrm{Zn} \mathrm{ha}^{-1}$ dose might be due to antagonistic effect between $\mathrm{P}$ and $\mathrm{Zn}$. Singh and Pandey (2018) reported similar results.

Table 2: Effect of sulphur and zinc on uptake of $\mathrm{N}, \mathrm{P}, \mathrm{S}\left(\mathrm{kg} \mathrm{ha}^{-1}\right)$ and zinc $\left(\mathrm{g} \mathrm{ha}^{-1}\right)$ by pearl millet (mean of 2 year)

\begin{tabular}{|c|c|c|c|c|c|c|c|c|}
\hline \multirow{2}{*}{ Soil Treatment } & \multicolumn{2}{|c|}{ Nitrogen } & \multicolumn{2}{|c|}{ Phosphorus } & \multicolumn{2}{|c|}{ Sulphur } & \multicolumn{2}{|c|}{ Zinc } \\
\hline & Grain & Straw & Grain & Straw & Grain & Straw & Grain & Straw \\
\hline \multicolumn{9}{|l|}{ Sulphur ( $\left.\mathrm{Kg} \mathrm{ha}^{-1}\right)$} \\
\hline 0 & 47.7 & 38.3 & 5.3 & 6.7 & 5.9 & 7.5 & 59.0 & 191.5 \\
\hline 10 & 52.8 & 43.7 & 6.4 & 8.2 & 7.0 & 9.9 & 67.8 & 215.5 \\
\hline 20 & 58.3 & 49.0 & 7.2 & 10.0 & 8.2 & 12.2 & 75.9 & 236.5 \\
\hline 40 & 58.4 & 60.8 & 7.4 & 10.0 & 8.5 & 12.8 & 72.7 & 227.1 \\
\hline CD (0.05) & 3.1 & 4.5 & 0.61 & 0.45 & 0.37 & 0.41 & 5.7 & 12.8 \\
\hline \multicolumn{9}{|l|}{ Zinc $\left(\mathrm{kg} \mathrm{ha}^{-1}\right)$} \\
\hline 0 & 50.5 & 41.2 & 5.5 & 7.1 & 6.5 & 8.5 & 55.8. & 182.3 \\
\hline 2 & 52.9 & 43.9 & 6.3 & 8.1 & 7.3 & 10.5 & 63.1 & 208.1 \\
\hline 4 & 58.1 & 49.1 & 7.2 & 10.5 & 8.3 & 12.2 & 73.3 & 245.8 \\
\hline 6 & 56.9 & 46.6 & 7.3 & 9.2 & 7.7 & 10.6 & 79.0 & 233.4 \\
\hline CD (0.05) & 3.1 & 4.5 & 0.61 & 0.45 & 0.37 & 0.41 & 5.7 & 12.8 \\
\hline
\end{tabular}

Sulphur uptake increased significantly along with the rise in the level of $S$ which varied from 5.9 to $8.5 \mathrm{~kg} \mathrm{ha}^{-1}$ in grain and from 7.5 to $12.8 \mathrm{~kg} \mathrm{ha}^{-1}$ in stover. Since the nutrients uptake is a function of their contents in crop plants and yield of crop, the increase in these parameters due to $S$ addition led to an increased uptake of nutrients (Yadav and Singh 2021). Sulphur uptake by grain and stover of pearl millet increased significantly with zinc addition over control and maximum values of $S$ uptake were recorded with $4 \mathrm{~kg} \mathrm{Zn} \mathrm{ha}^{-1}$ (Singh and Pandey 2018). Effect of $S$ application on $Z n$ uptake by grain and stoves of pearl millet was found to be significant. The increase in $\mathrm{Zn}$ uptake by grain and stoves was from 59.0 to 75.9 and 191.5 to
$236.5 \mathrm{~g} \mathrm{ha}^{-1}$, respectively with the application of $20 \mathrm{~kg} \mathrm{~S} \mathrm{ha}^{-1}$. Zinc application had a significant beneficial effect on its uptake by pearl millet grain and stover and highest values were recorded with $6 \mathrm{~kg} \mathrm{Zn} \mathrm{ha}^{-1}$. This increase could be attributed to the priming effect caused by higher crop growth on yield (Singh and Singh 2017).

\section{Residual effect on lentil}

The residual effect of $S$ levels had significantly beneficial effect on grain and straw yield of lentil over control when $40 \mathrm{~kg} \mathrm{~S} \mathrm{ha}^{-1}$ was applied in preceding pearlmillet crop. The increases in grain and straw yield of lentil with 40 
$\mathrm{kg} \mathrm{S} \mathrm{ha-1}$ were 18.6 and $15.8 \%$, respectively over control. The increase in lentil yield may be attributed to the buildup of sulphur in the soil which results in better root growth and subsequently the lentil yield (Ali et al.2013). Significantly highest grain yield $\left(1.90 \mathrm{t} \mathrm{ha}^{-1}\right)$ of lentil was recorded under residual effect of $6 \mathrm{~kg}$ $\mathrm{Zn} \mathrm{ha-1}$. With the application of $6 \mathrm{~kg} \mathrm{Zn} \mathrm{ha}^{-1}$, increase of $16.7 \%$ was recorded in lentil grain yield over control. The corresponding increase in straw yield was 14.0 per cent. The response of $\mathrm{Zn}$ application may be attributed to the enhancement of $\mathrm{Zn}$ control in soil. These results are in accordance with those reported by Upadhyay (2013).
Residual effect of sulphur up to $40 \mathrm{~kg} \mathrm{ha}^{-1}$ significantly improved the protein content and yield in lentil grain from 22.8 to $23.2 \%$ and 367.0 to $466.0 \mathrm{~kg} \mathrm{ha}^{-1}$. This may be attributed to significant role of $S$ in protein synthesis and nitrogen metabolism in the plant. Singh et al (2016) also reported similar results. There was a consistent and significant increase in protein content and yield with zinc application. The maximum protein content ( $23.1 \%$ ) in grain was recorded with $6 \mathrm{~kg} \mathrm{Zn} \mathrm{ha}^{-1}$ applied in preceding pearl millet crop. The increase in protein yield with residual $\mathrm{Zn}$ may be attributed to increased grain yield and protein content in lentil grain (Singh and Singh 2017).

Table 3: Effect of sulphur and zinc on uptake of N,P,S $\left(\mathrm{kg} \mathrm{ha}^{-1}\right)$ and zinc $\left(\mathrm{g} \mathrm{ha}^{-1}\right)$ by lentil crop (mean 2 year)

\begin{tabular}{|c|c|c|c|c|c|c|c|c|}
\hline \multirow{2}{*}{ Treatment } & \multicolumn{2}{|c|}{ Nitrogen } & \multicolumn{2}{|c|}{ Phosphorus } & \multicolumn{2}{|c|}{ Sulphur } & \multicolumn{2}{|c|}{ Zinc } \\
\hline & Grain & Straw & Grain & Straw & Grain & Straw & Grain & Straw \\
\hline \multicolumn{9}{|c|}{ Sulphur $\left(\mathrm{kg} \mathrm{ha}^{-1}\right)$} \\
\hline 0 & 58.7 & 23.1 & 4.0 & 3.1 & 3.5 & 3.1 & 39.4 & 58.7 \\
\hline 10 & 63.4 & 24.9 & 4.4 & 3.5 & 4.1 & 3.5 & 43.5 & 64.6 \\
\hline 20 & 70.6 & 27.8 & 5.1 & 4.1 & 5.1 & 4.3 & 50.6 & 72.4 \\
\hline 40 & 70.1 & 28.0 & 5.2 & 4.3 & 5.2 & 4.5 & 47.2 & 65.3 \\
\hline CD (0.05) & 3.0 & 1.9 & 0.38 & 0.35 & 0.47 & 0.39 & 3.39 & 5.14 \\
\hline \multicolumn{9}{|l|}{ Zinc $\left(\mathrm{kg} \mathrm{ha}^{-1}\right)$} \\
\hline 0 & 60.0 & 23.6 & 4.2 & 3.4 & 3.9 & 3.4 & 36.4 & 54.3 \\
\hline 2 & 63.2 & 24.9 & 4.6 & 3.7 & 4.3 & 3.7 & 41.2 & 62.3 \\
\hline 4 & 78.3 & 27.9 & 5.3 & 4.3 & 4.9 & 4.3 & 49.7 & 72.9 \\
\hline 6 & 67.2 & 27.2 & 4.5 & 3.6 & 4.7 & 4.0 & 52.7 & 72.5 \\
\hline CD (0.05) & 3.0 & 1.9 & 0.38 & 0.35 & 0.47 & 0.39 & 3.39 & 5.14 \\
\hline
\end{tabular}

Application of $S$ increased the uptake of $\mathrm{N}$ by lentil grain and straw over control. Increased uptake of $\mathrm{N}$ might be attributed to the corresponding increase in $\mathrm{N}$ concentration and grain and straw yield (Ali et al. 2013). There was a significant increase in $\mathrm{P}$ uptake by lentil crop with increasing levels of residual sulphur and maximum values were recorded with $40 \mathrm{~kg} \mathrm{~S}$ ha 1 . The $S$ uptake increased significantly with the increase in residual $S$ levels from 0 to $40 \mathrm{~kg} \mathrm{ha}^{-1}$ Since, the nutrient uptake is a function of their contents in grain and straw and yield of the crop, the increase in these parameters due to $S$ addition led an increased uptake of nutrients (Yadav and Singh 2021). The significant residual effect of sulphur on zinc uptake by grain and straw of succeeding lentil crop was observed up to $20 \mathrm{~kg} \mathrm{~S} \mathrm{ha}^{-1}$ (Ali et al.2013). Application of 40 $\mathrm{kg} \mathrm{S} \mathrm{ha-1} \mathrm{resulted} \mathrm{in} \mathrm{significant} \mathrm{decrease} \mathrm{in} \mathrm{zinc}$ uptake over $20 \mathrm{~kg} \mathrm{~S} \mathrm{ha}^{-1}$. This reduction in $\mathrm{Zn}$ uptake owing to $S$ application may be due to antagonistic relation between $\mathrm{Zn}$ and Sulphur. Data present in table 3 indicated that uptake of nitrogen, phosphorus, sulphur and zinc was significantly influenced by residual effect of zinc .Highest values of $N\left(78.3\right.$ and $\left.27.9 \mathrm{~kg} \mathrm{ha}^{-1}\right), P$ $\left(5.3\right.$ and $\left.4.3 \mathrm{~kg} \mathrm{ha}^{-1}\right), \mathrm{S}\left(4.9\right.$ and $\left.4.3 \mathrm{~kg} \mathrm{ha}^{-1}\right)$ in lentil grain and straw, respectively was recorded with $4 \mathrm{~kg} \mathrm{Zn} \mathrm{ha-1}$. The lowest value of these nutrients in crop was recorded in control. The increase in uptake of these nutrients with $\mathrm{Zn}$ addition was also reported by Upadhyay (2013) in lentil. $\mathrm{Zn}$ uptake by lentil crop increased significantly with zinc levels and maximum values by $\mathrm{Zn}$ uptake by grain $\left(52.7 \mathrm{~g} \mathrm{ha}^{-1}\right)$ and straw $\left(72.5 \mathrm{~g} \mathrm{ha}^{-1}\right)$ of lentil were recorded with 6 $\mathrm{kg} \mathrm{Zn} \mathrm{ha}{ }^{-1}$ (Singh and Singh 2017). 
From the results, it may be concluded that $40 \mathrm{~kg} \mathrm{~S}$ and $6 \mathrm{~kg} \mathrm{Zn} \mathrm{ha}^{-1}$ addition in pearl millet crop were optimum doses for obtaining higher productivity, quality of produce and

\section{REFERENCES}

Ali, J., Singh, S.P. and Singh, S. (2013) Research of fababean to boron, zinc and sulphur application in alluvial soil. Journal of the Indian Society of Soil Science 61 (3) : 202-206

Chauhan, T.M., Ram Lakhan and Singh, V (2017) Effect of potassium and sulphur on yield of and nutrient uptake by pearl millet (Pennisetum glaucum) in alluvial soil. Annals of Plant and Soil Research 19 (4): 434-443.

Chesnin, L. and Yien, C.H.(1951) Turbidimetric determination of available sulphate. Soil Science Society of America Proceedings $15: 149-151$

Jackson, M.L. (1973) Soil Chemical Analysis. Prentice Hall of India Private Limited, New Delhi.

Singh, R., Singh, U.N., Chauhan, T.M. and Singh, V. (2020) Sulphur fertilization for enhancing the productivity of pearl millet (Pennisetum glaucum) and Soil fertility in alluvial soil. Annals of Plant and Soil Research 22 (1) : 96-99

Singh, S. and Singh, V. (2017) Productivity, quality and nutrients uptakes of some rabi crops under zinc nutrition in alluvial soil. Annals of Plant and Soil Research 19 (4) : 355-359

Singh, S., Singh, J.P., Khan, M.H., Pal,A.K. and Kumar, S. (2016) Effect of sulphur on utilization of nutrients by the crops under pearl millet lentil cropping sequence in Agra district of Uttar Pradesh.

yield, nutrient uptake and economics of pearl millet (Pennisetum glaucum) and lentil (lens culinaris) grown in sequence on an alluvial soil. Indian Journal of Agricultural Sciences 86 (12): 15811585

Singh, V. and Pandey, M.(2018) Direct effect of sulphur and zinc on productivity, quality and nutrient uptake by pearl millet (Pennisetum glaucum) and their residual effect on succeeding wheat (Triticum aestivum) in pearl millet-wheat crop sequence. Annals of Plant and Soil Research 20_(3) : 233-238

Singh, V. (2020) Response of fodder sorghum (Sorghum bicolor L.) to levels of sulphur in alluvial soil. Annals of Plant and soil Research 21 (21)

Singh,U.N. and Singh, V. (2020) Effect of sources and levels of sulphur on yield, quality and uptake of nutrients in pearl millet (Pennisetum glaucum) and wheat (Triticum aestivum) grown in sequence on an alluvial soil. Annals of Plant and Soil Research. 22 (3): 234-238

Upadhyay, A.K (2013) Effect of sulphur and zinc nutrient on yield, uptake of nutrients and quality of lentil in alluvial soil. Annals of Plant and Soil Research 15 (2): 160163. 